\title{
COLOR STABILITY OF STRAWBERRY JAM FORTIFIED BY PURPLE CARROT PUREE
}

\author{
ABDEL-HADY, M. M., GAMILA Y. ATTIA and AFAF M. ALI \\ Food Technology Research Institute, ARC, Giza, Egypt
}

(Manuscript received 20 January 2014)

\begin{abstract}
The discoloration of strawberry products due to the rapid degradation of pigments is considered as one of the most quality defects that affect their acceptance. Therefore, in the present study, the objective was to investigate the possibility to improve the color stability of strawberry jam by using purple carrot puree. The obtained results declared that purple carrot puree characterized by high content of anthocyanins and total phenols compared to strawberry puree. Furthermore, the contents of individual anthocyanins were analyzed by HPLC. The highly stable acylated anthocyanins pigments represented $66.64 \%$ of total anthocyanins in purple carrot compared to $20.6 \%$ from strawberry. Cyandin-3-xylosyl-glucosyl-galactoside acylated with Ferulic acid was the predominant anthocyanin in purple carrot while Pelargonidin 3-glcosside was the major component in strawberry. Purple carrot puree was adding by 15,20 and $30 \%$ to strawberry puree during jam processing. The jams were monitored over a period of 6 month of storage under normal conditions of light exposure and room temperature. The results revealed that $\mathrm{pH}$ value, viscosity, total anthocynin and total phenol contents were increased gradually by increasing the amount of purple carrot and markedly decreased the degradation of anthocyanin during storage period by $53.2,52.9,18.0$ and $7.3 \%$ in control, 15,20 and $30 \%$ samples respectively. Furthermore, the color of jams were controlled during the storage period. $\mathrm{L}^{*}, \mathrm{a}^{*}, \mathrm{~b}^{*}$, hue ${ }^{\circ}$ and chroma values showed that the color of strawberry jams containing purple carrot was improved and showed stability. The results of sensory evaluation revealed that the jam of $20 \%$ purple carrot treatment obtained the highest overall acceptability score at the end of storage period.

Finally, from all results obtained, it can be concluded that the addition of purple carrot up to $20 \%$ during strawberry jam processing maintained the color of jam without any effect on their acceptance.
\end{abstract}

\section{INTRODUCTION}

Besides flavor, texture and economic considerations, color is one of the most important attributes affecting consumer acceptance of food. Color stability, particularly after heat and light exposure, remains a challenge. Therefore, both natural and synthetic colorants are added to processed food to compensate for varying quality and to restore initial appearance, but also to color food, which would otherwise be unattractive or unappealing (Stintzing et al., 2002). 
Strawberries (Fragaria ananassa), that are one of the most popular fruits worldwide, are rich in nutrients such as amino acids, vitamins and anthocyanins. Loss of quality in this fruit is mostly due to its relatively high metabolic activity and sensitivity to fungal decay. Strawberries are also susceptible to water loss, bruising and mechanical injuries due to their soft texture and lack of a protective rind (Garcia et al., 1998). Strawberries are consumed mainly as fresh fruit. In addition, many other strawberry products such as juice, nectar, puree, and juice concentrate as well as jam are commercially available. Whereas fresh strawberries exhibit brilliant red colors, the processed fruits are characterized by rapid color loss and pigment degradation (Espin et al., 2000). Factors which affect the color and stability of anthocyanins include structure and concentration, $\mathrm{pH}$ value, temperature, light, presence of co pigments, self association, metallic ions, enzymes, oxygen, ascorbic acid, sugar and their degradation products, proteins and sulphur dioxide (Mazza and Miniati, 1993).

Natural red colorants permitted in foods include betanin, cochineal (carmine and carminic acid), carotenoids and anthocyanins (Askar,1993). Anthocyanins(ACs) are glycosides of polyhydroxy and polymethoxy derivatives of flavylium cation. Recent studies demonstrated that polyphenolic flavonoids exhibit a wide range of biological, pharmacological and chemoprotective properties as free radical scavengers preventing oxidation and cancer initiation (Kong et al., 2003). Commercial anthocyanin colorants are mostly derived from fruits and vegetables. These sources include red grape, elderberry, black currant, blackberry, raspberry, black chokeberry, red cabbage, purple carrot, purple corn, red radish and purple sweet potato. The largest natural commercial source for anthocyanins is red grape skin, followed by elderberry, purple carrot and red cabbage ( Downham and Collins, 2000).

Carrot (Daucus carota L.) is one of the main vegetable crops grown in temperate climate regions. Carrot originates from the wild forms growing in Europe and southwestern Asia. The first cultivated carrot types were purple or violet. Later yellow and orange types we rederived from this anthocyanin type, by selection process (Banga 1984). Purple carrot (or black carrot as it sometimes referred to) is an all natural food colorant, offering a final color which can vary from deep violet to bright red. The color can be controlled by simply controlling the $\mathrm{pH}$ value. Purple carrots are a good source of anthocyanin pigments. The anthocyanin content of black carrots was reported to be $1750 \mathrm{mg} / \mathrm{kg}$ fresh weight (Mazza and Miniati, 1993). Anthocyanins from purple carrot were relatively stable to heat and $\mathrm{pH}$ change compared to anthocyanins from other sources due to diacylation of anthocyanin structure. Purple carrots also contain high amounts of acylated anthocyanins. Stintzing 
et al. (2002) identified four major anthocyanins in purple carrot extract and found $41 \%$ of anthocyanins to be acylated.

The usage of purple carrot anthocyanins as a natural colorant in the production of confectionery, jellies, jams, preserves and frozen desserts was discussed by Birks (1999). Alasalvar et al. (2001) reported that black carrots contain a high amount of nutraceutical components. Furthermore, Netzel et al. (2007) proved that anthocyanin rich extract from purple carrot inhibited proliferation of the both types of human cancer cells (colorectal adenocarcinoma and promyelocytic leukemia) in a dose dependent manner. Utilization of anthocyanin sources rich in (cyanidin, delephindin and petunidin) for food application may enhance health preventive effects. Due to the presence of cyanidinbased pigments purple carrot seems to be a suitable candidate for the development of health promoting foods.

The objectives of this study were to evaluate the effects of adding purple carrot puree on the color stability of strawberry jam.

\section{MATERIALS AND METHODS}

\section{Materials}

a) Purple carrot (Daucus carota L. sp. Sativus var. atrorubens.) and Strawberries ( Fragaria ananassa) used in this study (season 2013) were purchased from the local market in Giza governorate, Egypt.

b) The solvents used for spectral and HPLC analysis were of HPLC grade and all other solvents were of ACS grade.

c) Chemicals used in this study were of analytical grade and purchased from ElGomhoria Co.

d) The anthocyanin standards from Carl Roth GmbH (D-76185 Karlsruhe, Germany).

\section{Methods}

\section{Purple carrot puree preparation:}

Carrots were trimmed and washed by tap water, the roots cut into halves by stainless knife. The endoderm parts removed while the cortex were collected and blanched in boiling water for 5 minutes then pureed using an electrical mixer blender and screened by a piece of muslin cloth to obtain homogenized puree.

\section{Strawberry puree preparation:}

Strawberry fruits were sorted, the hulls and stem were carefully removed by stainless knife and washed by tap water then pureed using an electrical mixer blender and screened by a piece of muslin cloth to obtain homogenized puree. 


\section{Strawberry jam preparation:}

Strawberry jam was processed according to the Egyptian Standard (ES) No.129 part 2 (2005). Different strawberry jams were prepared using different ratios of purple carrot puree and other materials, listed in Table (1). The mixture of strawberry, carrot puree and sugar was cooked in an open pan with continues manual stirring till total soluble solids reached to $65^{\circ}$ Brix. The hot jams were filled into glass jars (400 $\mathrm{ml}$ ) then tightly closed and stored at room temperature.

Table 1. Recipes of strawberry jams fortified by purple carrot puree.

\begin{tabular}{|l|c|c|c|c|c|}
\hline Ingredients & $\begin{array}{c}\text { Sucrose } \\
(\mathrm{g})\end{array}$ & $\begin{array}{c}\text { Strawberry } \\
\text { puree }(\mathrm{g})\end{array}$ & $\begin{array}{c}\text { Carrot puree } \\
(\mathrm{g})\end{array}$ & $\begin{array}{c}\text { Citric acid } \\
(\mathrm{g}) / \mathrm{kg}\end{array}$ & $\begin{array}{r}\text { Commercial } \\
\text { citrus pectin } \\
(\mathrm{g}) / \mathrm{kg}\end{array}$ \\
\hline Control & 1100 & 1000 & --- & 4.0 & 5.0 \\
\hline Jam with $15 \%$ carrot & 1100 & 850 & 150 & 4.0 & 5.0 \\
\hline Jam with $20 \%$ carrot & 1100 & 800 & 200 & 4.0 & 5.0 \\
\hline Jam with 30\% carrot & 1100 & 700 & 300 & 4.0 & 5.0 \\
\hline
\end{tabular}

\section{Analytical methods}

Moisture content, total soluble solids, total titratable acidity, pH values, ascorbic acid and ash were determined according to AOAC (2005).

Browning index was determined according to the method of Meydev et al, (1977), as its light absorbance at $420 \mathrm{~nm}$

Viscosity was measured using Brookfield Viscometer DVIII Ultra Programmable Rheometer at rotation speed of $10 \mathrm{rpm}$, using spindle No. HA-0 7 at $25^{\circ} \mathrm{C}$ following the method of Askar and Treptow (1993).

The yield was calculated from the amount of puree obtained from $100 \mathrm{~g}$ raw fruit

\section{Total anthocyanin:}

The total anthocyanin was determined as reported by Mondello et.al.(2000). Ten gm of sample were filtered through glass wool, and the pulp washed with $90 \mathrm{ml}$ of a Ethanol : $\mathrm{HCl}$ mixture previously prepared mixing $79.7 \mathrm{ml}$ of anhydrous ethyl alcohol with $20.3 \mathrm{ml}$ of $\mathrm{HCl}(37 \%)$. The volume was made up $100 \mathrm{ml}$ by solvent. The absorbance has been measured at $535 \mathrm{~nm}$, by spectrophotometer (Jenway 6405 UV/visible), using $1 \mathrm{~cm}$ cells. The qualification was done with respect to standard curve of cyaniding-3-glucoside. The results were expressed as cyaniding-3glucoside equivalent ( $\mathrm{mg}$ per $100 \mathrm{ml}$ of sample). 


\section{Analysis of anthocyanins of strawberry and purple carrots extract:}

\section{Purification of anthocyanins:}

The anthocyanins concentrated extract was purified according to the method of (Attoe and Van-Elbe, 1981). The concentrate of anthocyanin was purified with petroleum ether and with ethyl acetate to remove non polar impurities. After phase separation; residual solvent was removed from the aqueous phase with rotary evaporator.

Identification of anthocyanins pigments by High-Performance Liquid Chromatography (HPLC) :

The purified anthocyanin of purple carrots was identified by HPLC according to the method reported by (Andersen, 1989) using suplecosil LC 18 column .For both HPLC column of two solvents were used for elution the first was formic acid, water (1:9) and the second formic acid, water, methanol (1:4:5). The flow rate was $1.5 \mathrm{ml} / \mathrm{min}$. The elutes were monitored by visible spectrometry at max. wavelength $520 \mathrm{~nm}$.

\section{Color measurement:}

The color of samples ( $L^{*}, a^{*}$ and $\left.b^{*}\right)$ was measured with a Minolta Chroma Meter (CM- 3600d, Minolta, and Ramsey, NJ). To prepare the samples for color measurement, purees and jam samples were poured into a 35-mm Petri dish and carefully covered with a Saran Wrap transparent film which was carefully pressed against surface to remove air bubbles as reported by Abonyi et. a/(2001). Color of the samples was measured by contacting the color meter with the film-covered sample. Measurements were taken at 5 different locations on the sample. At each location 5 readings were taken. The mean of 25 readings was reported. A darkness factor $\mathrm{b} * / \mathrm{a} *$ was used to quantify possible color changes (Tulasidas et al., 1993). The hue angle $\left(\mathrm{H}^{*}\right)$ and chroma $\left(\mathrm{C}^{*}\right)$ which are given by $\mathrm{H}^{*}=\tan -{ }^{1}\left(\mathrm{~b}^{*} / \mathrm{a}^{*}\right)$ and $\mathrm{C}^{*}=\left(\mathrm{a}^{* 2}+\right.$ $\left.b^{* 2}\right)^{1 / 2}$ were also calculated.

\section{Determination of total phenols content:}

Total phenol contents (TPC) of samples was determined spectrophotometrically by a spectrophotometer (Jenway 6405 UV/visible) using the Folin \& Ciocalteu assay described by Vinson et al.(1995) . One gm of sample was mixed with $1 \mathrm{ml}$ of $6 \mathrm{M} \mathrm{HCl}$ and $5 \mathrm{ml}$ of $75 \%$ methanol / water solution in a screw-capped tube. The tube was vortexed and placed in a $90^{\circ} \mathrm{C}$ water bath and shaken for $2 \mathrm{~h}$. Then, the tube was allowed to cool to room temperature and diluted to a $10 \mathrm{ml}$ volume with distilled water. One milliliter of this solution was mixed with $5 \mathrm{ml}$ of previously tenfold diluted Folin \& Ciocalteau reagent. Fifteen milliliters of $\mathrm{Na2CO} 3(7 \mathrm{~g} / 100 \mathrm{ml})$ were added to this mixture to produce basic conditions. The mixture was diluted to $100 \mathrm{ml}$ with distilled water. The absorbance versus prepared blank was read at $760 \mathrm{~nm}$ until it 
reached steady state. The same procedure was applied for six standard solutions of Gallic acid (50-300 mg/100 ml). Final results were expressed as $\mathrm{mg}$ Gallic equivalent per $100 \mathrm{ml}$ of juice.

\section{Sensory evaluation:}

Sensory evaluation of the different tested juices were carried out using the method of Howard and Dewi (1995) by ten staff members for color (10), texture (10), taste (10), and aroma (10) .The overall acceptability was calculated from the total scores of the tested attributes.

The organoleptic data were statistically analyzed using the ANOVA procedure of the SPSS statistical package for IBM computer (SPSS, 1990).

\section{RESULTS AND DISCUSSION}

\section{Chemical properties of purple carrot and strawberry puree:}

Results in Table (2) show comparison between some physicochemical properties of purple carrot and strawberry purees. The obtained results declared that strawberry puree was higher in TSS, total acidity, ascorbic acid while purple carrot puree was the slightly higher in yield, moisture content and $\mathrm{pH}$ value but the highest by two or three folds in viscosity, total anthocyanins and total phenols.

Table 2. Physicochemical composition of purple carrot and strawberry purees.

\begin{tabular}{|l|l|l|}
\hline Parameter & Purple carrot & Strawberry \\
\hline Yield ${ }^{*}$ & 88.7 & 82.3 \\
\hline Moisture content \% & 93.4 & 92.6 \\
\hline TSS $\left({ }^{\circ}\right.$ Brix) & 6.7 & 7.3 \\
\hline Total acidity & 0.08 & 0.72 \\
\hline $\mathrm{pH}$ value & 6.1 & 3.4 \\
\hline Ascorbic acid $(\mathrm{mg} / 100 \mathrm{~g})$ & 15.5 & 17.8 \\
\hline Viscosity (centipoises) & 88.0 & 34.7 \\
\hline Total anthocyanin $(\mathrm{mg} / 100 \mathrm{~g})$ & 172.4 & 38.3 \\
\hline Total phenols $(\mathrm{mg} / 100 \mathrm{~g})$ & 465.3 & 243.7 \\
\hline
\end{tabular}

\section{Identification of purple carrot and strawberry purees anthocyanins:}

The anthocyanin pigments of both purple carrot and strawberry purees were analyzed and identified by HPLC as shown in Fig.1( $a$ and $b$ ) and Table (3). Purple carrot anthocyanins comprise high amount of acylated cyanidin derivatives which exhibit remarkable stability to $\mathrm{pH}$ value changes and heat treatment (Stintzing et al.,2002). The acylated anthocyanin pigments from purple carrot puree represented about $66.64 \%$ of total anthocyanins compared to $20.6 \%$ from strawberry. Yoshida et al. (1991) reported that acylated anthocyanins are protected from the hydrophilic attack of water molecules by the acyl moieties (intramolecular effect). 
Beside improving the stability, the acylated anthocyanins display enhanced biological activities, anthocyanins possess strong radical-scavenging, antimutagenic activities and anti-hypertensive effects (Suda et al.,2003). Cyandin-3xylosyl-glucosyl-galactoside acylated with Ferulic acid was the predominant compound (33.65) followed by Cyandin-3-xylosyl-glucosyl-galactoside acylated with Coumaric acid (29.85) in purple carrot while Pelargonidin 3-glcosside was the major component which represented about $68.2 \%$ of total chromatogram area in strawberry. However these results in general were in accordance with Kammerer et al. (2007).


Fig. 1. HPLC chromatogram of anthocyanin pigments extracted from purple carrots (a) and strawberry (b). 
Table 3. Identification of anthocyanin pigments extracted from purple carrots and strawberry purees.

\begin{tabular}{|l|c|c|}
\hline \multirow{2}{*}{ Identified anthocyanin } & \multicolumn{2}{|c|}{ Area \% } \\
\cline { 2 - 3 } & Purple carrot & Strawberry \\
\hline Cyandin-3-xylosyl-glucosyl-galactoside & 4.65 & - \\
\hline Cyandin-3-xylosyl-galactoside & 28.70 & - \\
\hline $\begin{array}{l}\text { Cyandin-3-xylosyl-glucosyl-galactoside - acylated with } \\
\text { sinapic acid }\end{array}$ & 3.24 & - \\
\hline $\begin{array}{l}\text { Cyandin-3-xylosyl-glucosyl-galactoside acylated with } \\
\text { ferulic acid }\end{array}$ & 33.65 & - \\
\hline $\begin{array}{l}\text { Cyandin-3-xylosyl-glucosyl-galactoside acylated with } \\
\text { coumaric acid }\end{array}$ & 29.85 & 13.5 \\
\hline $\begin{array}{l}\text { Cyandin 3-glcoside } \\
\text { Pelargonidin 3-glcosside }\end{array}$ & - & 68.2 \\
\hline Pelargonidin-3-glcoside- acylated with malic acid & - & 19.7 \\
\hline Pelargonidin-3-glcoside- acylated with succinic acid & - & 0.9 \\
\hline
\end{tabular}

\section{Physical and chemical properties of strawberry - purple carrot jam :}

The influence of using different levels of purple carrot puree as a colorant agent on the quality parameters of prepared strawberry jam during 6 month of storage are shown in Table (4). The results indicate that $\mathrm{pH}$ values were gradually increased by both increasing the level of carrot puree and storage period on the other hand viscosity was also increased as increasing carrot puree but decreased during the storage. Data in Table indicate that browning index was increased during storage in all treatments but with lower rates in case of adding purple carrot may be to reducing the formation of Millard reaction products (Kammerer et al., 2007).

Initially, data indicated that the total anthocyanins concentration was increased significantly with increasing the level of adding purple puree which degraded gradually during the storage period, much faster degradation rate of anthocyanin was noticed in control and $15 \%$ purple carrot treatments. Furthermore, the anthocyanins in the jams of strawberry fortified by purple carrot showed a greater stability than those from strawberry one. These results are closed with those reported by Kirca, et al. (2006) and Stintzing et al. (2002) who indicated that the higher stability of anthocyanins is due to the high degree of acylation enabling intra-molecular copigmentation effects. The same tendencies were also observed for total phenols, they increased by increasing the amount of purple carrot and the degradation rate of total phenols from control jam was higher compared with the other purple carrot treatments. Concerning to total phenols, it is will know that phenols play role as antioxidant agent and correlated with the antioxidant capacity of fruits (Prior et al., 1998). This result proved that mixing the purple carrot puree with strawberry decrease the degradation rate of pigment during storage and promote the hidden quality indices of strawberry jam. 
Table 4. Effect of adding purple carrot on some properties of strawberry jam.

\begin{tabular}{|c|c|c|c|c|c|}
\hline \multirow[t]{2}{*}{ Parameter } & \multirow{2}{*}{$\begin{array}{c}\text { Storage } \\
\text { period } \\
\text { (month) }\end{array}$} & \multicolumn{4}{|c|}{ Level of carrot puree $\%$} \\
\hline & & control & $15 \%$ & $20 \%$ & $30 \%$ \\
\hline \multirow[t]{3}{*}{$\mathrm{PH}$ value } & 0 & 3.2 & 3.4 & 3.4 & 3.5 \\
\hline & 3 & 3.5 & 3.6 & 3.6 & 3.7 \\
\hline & 6 & 3.9 & 3.8 & 3.8 & 4.0 \\
\hline \multirow[t]{3}{*}{ Viscosity (Centipoises) } & 0 & 72.4 & 96.5 & 112.6 & 140.3 \\
\hline & 3 & 58.7 & 82.4 & 98.7 & 113.4 \\
\hline & 6 & 46.9 & 65.5 & 82.9 & 94.6 \\
\hline \multirow[t]{3}{*}{ Color index } & 0 & 0.246 & 0.242 & 0.247 & 0.256 \\
\hline & 3 & 0.278 & 0.274 & 0.268 & 0.259 \\
\hline & 6 & 0.315 & 0.298 & 0.278 & 0.264 \\
\hline \multirow[t]{3}{*}{ Total anthocyanin $(\mathrm{mg} / 100 \mathrm{~g})$} & 0 & 26.7 & 34.3 & 39.4 & 58.9 \\
\hline & 3 & 17.8 & 19.6 & 35.6 & 56.4 \\
\hline & 6 & 12.5 & 16.2 & 32.3 & 54.6 \\
\hline \multirow[t]{3}{*}{ Total phenols $(\mathrm{mg} / 100 \mathrm{~g})$} & 0 & 156.8 & 179.3 & 196.4 & 212.5 \\
\hline & 3 & 138.7 & 168.1 & 187.5 & 204.8 \\
\hline & 6 & 114.5 & 155.4 & 180.6 & 198.4 \\
\hline
\end{tabular}

\section{Color changes:}

The color changes in strawberry jams samples as affected by different levels of purple carrots during 6 months of storage at room temperature are shown in Fig.(2 and 3). The control strawberry jam (prepared without any purple carrot) had a brighter color (highest $L^{*}$ ) than the other treatments contained purple carrot. A gradual increase during storage in $L^{*}$ values was observed in control sample compared to a slight differences in colored jams due to occurring a pigment degradation resulting in color bleaching as mentioned by Espin et al. ( 2000). Otherwise, the addition of purple carrot puree during strawberry jam processing enhanced both $a^{*}$ (redness) and $b^{*}$ values and showed a slight decrease throughout storage.

Hue angles (Fig.2) of the control samples were significantly increased compared to other treatments which, in combination with a comparatively low chroma value, describes the pale-brownish color of the processed jam. Besides thermal pigment degradation, Maillard reactions may also be responsible for the formation of brown compounds as explained by Kammerer et al. (2007). The strawberries mixed with purple carrot anthocyanins exhibited a slightly lower hue value. This effect was more pronounced when the jams were stored. Accordingly, chroma values of the control samples recorded lower value compared with purple carrots treatments. Since chroma reflects color brilliance or purity and is correlated with the degree of anthocyanin acylation (Kammerer,2007). The loss of brilliance was less pronounced when purple carrot were used for color promotion. 


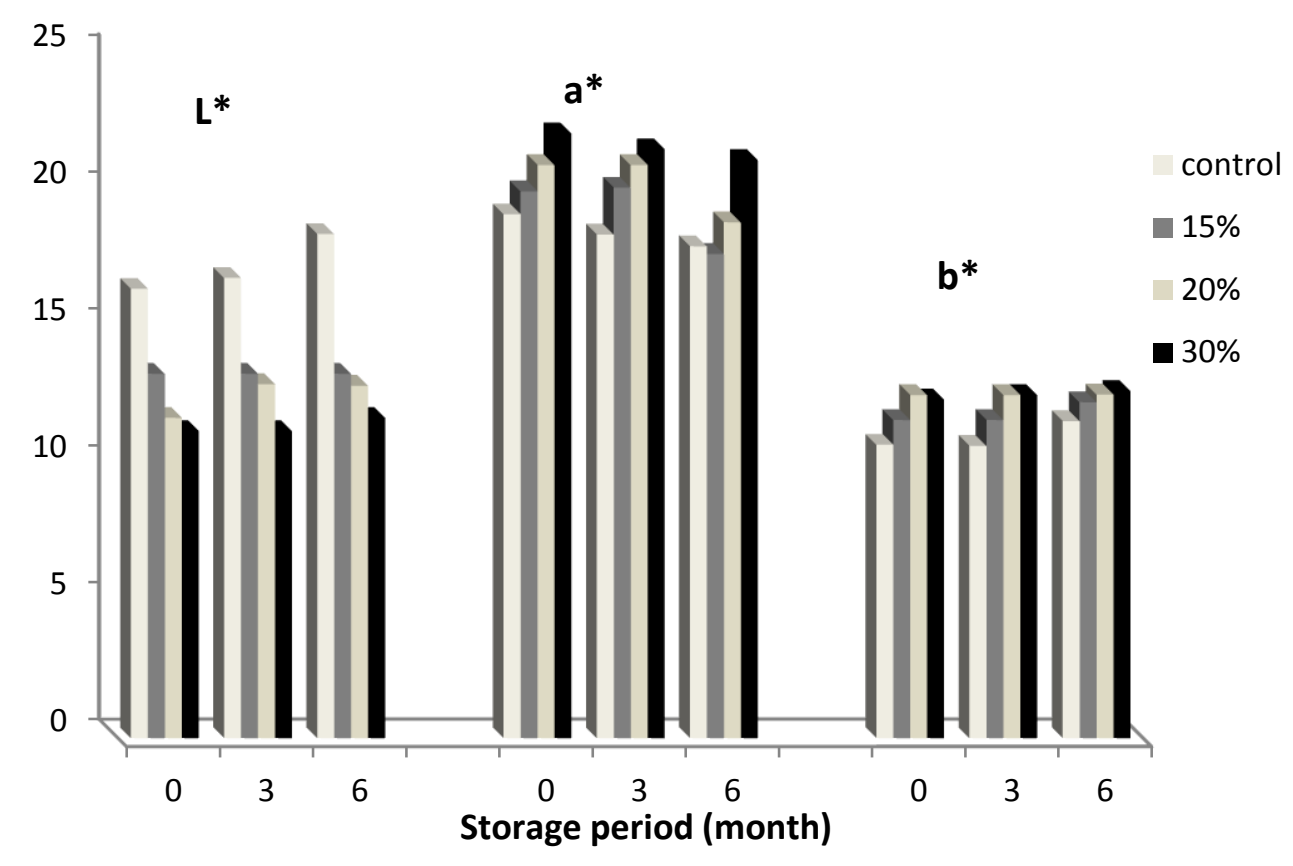

Fig 2. $L *, a *$ and $b *$ of strawberry jams mixed with purple carrot.

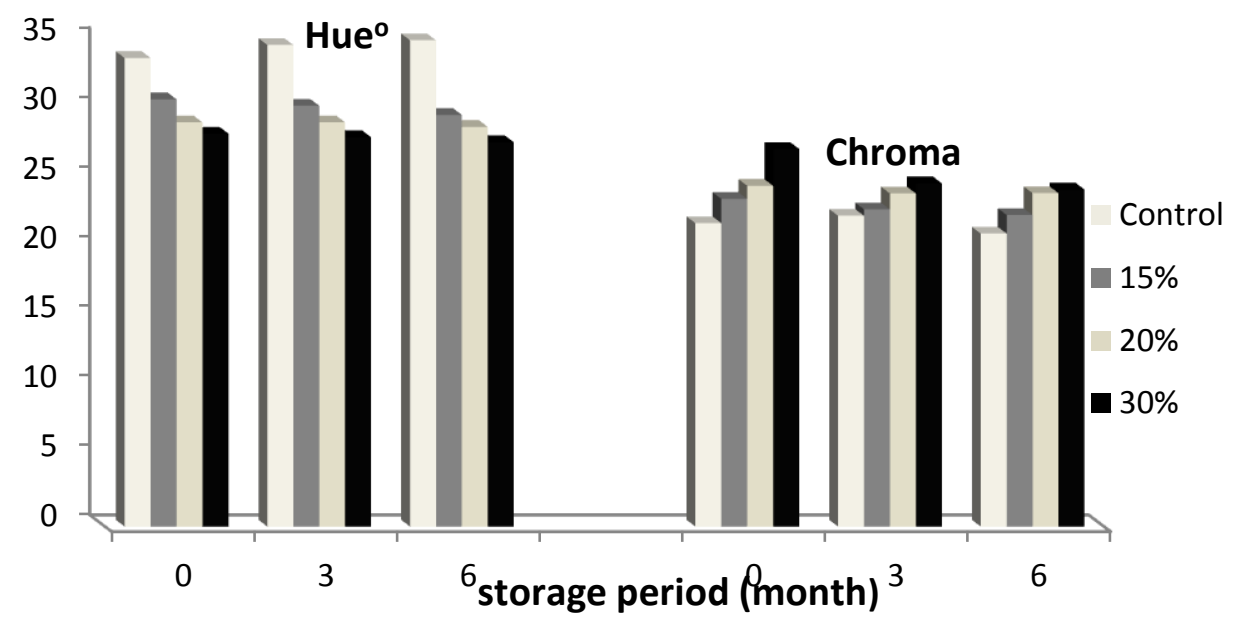

Fig. 3. Hue ${ }^{\circ}$ and chroma of strawberry jams mixed with purple carrot.

\section{Organoleptic properties:}

Results in Table (5) represent the effect of using purple carrot for promotion of color stability of strawberry jam. It could be observed that sensory attributes decrease gradually after storage for six months at room temperature in all tested samples. The highest overall acceptability score after six months of storage was noticed for jam of strawberry mixed with $20 \%$ purple carrot. Data showed no significant differences between the color, texture, taste, aroma and overall acceptability in both control and $15 \%$ purple carrot samples at zero time. In contrast, after six months of storage the 
addition of purple carrot with different levels significantly affected color and texture where the highest score were recorded in both 20 and 30\% purple carrot samples while taste and aroma reduced slightly, no significant differences, were achieved between control and purple carrot addition up to $20 \%$.

Table 5. Sensory evaluation of strawberry jam fortified by purple carrot.

\begin{tabular}{|c|c|c|c|c|c|c|}
\hline Treatment & $\begin{array}{l}\text { Storage } \\
\text { period }\end{array}$ & Color & Texture & Taste & Aroma & Overall acceptability \\
\hline \multirow{3}{*}{ Control } & 0 & $9.2^{a b}$ & $9.4^{a}$ & $9.6^{a}$ & $9.7^{a}$ & $9.5^{a *}$ \\
\hline & 3 & $7.8^{c}$ & $8.7^{b}$ & $8.7^{b}$ & $8.6^{b c}$ & $8.5^{\mathrm{bc}}$ \\
\hline & 6 & $6.2^{\mathrm{e}}$ & $7.9^{c}$ & $8.5^{\mathrm{bc}}$ & $8.2^{c}$ & $7.7^{c}$ \\
\hline \multirow{3}{*}{$\begin{array}{l}\text { Strawberry }+15 \% \\
\text { purple carrot }\end{array}$} & 0 & $9.3^{\mathrm{a}}$ & $9.4^{a}$ & $9.5^{a}$ & $9.6^{\mathrm{a}}$ & $9.5^{\mathrm{a}}$ \\
\hline & 3 & $8.4^{\mathrm{bc}}$ & $8.8^{\mathrm{b}}$ & $8.7^{b}$ & $8.5^{b c}$ & $8.6^{b c}$ \\
\hline & 6 & $8.2^{c}$ & $8.6^{\mathrm{bc}}$ & $8.6^{b c}$ & $8.2^{c}$ & $8.4^{b c}$ \\
\hline \multirow{3}{*}{$\begin{array}{l}\text { Strawberry }+20 \% \\
\text { purple carrot }\end{array}$} & 0 & $9.5^{\mathrm{a}}$ & $9.8^{\mathrm{a}}$ & $9.2^{\mathrm{ab}}$ & $9.3^{\mathrm{ab}}$ & $9.5^{\mathrm{a}}$ \\
\hline & 3 & $9.2^{\mathrm{ab}}$ & $9.4^{\mathrm{a}}$ & $8.6^{\mathrm{b}}$ & $8.6^{\mathrm{b}}$ & $9.0^{\mathrm{ab}}$ \\
\hline & 6 & $8.7^{\mathrm{b}}$ & $8.8^{b}$ & $8.4^{b c}$ & $8.4^{\mathrm{bc}}$ & $8.6^{\mathrm{bc}}$ \\
\hline \multirow{3}{*}{$\begin{array}{l}\text { Strawberry }+30 \\
\% \text { purple carrot }\end{array}$} & 0 & $9.6^{a}$ & $9.6^{\mathrm{a}}$ & $8.6^{b}$ & $8.4^{b c}$ & $9.1^{\mathrm{a}}$ \\
\hline & 3 & $9.4^{\mathrm{a}}$ & $9.2^{\mathrm{ab}}$ & $8.2^{c}$ & $8.0^{c}$ & $8.7^{\mathrm{b}}$ \\
\hline & 6 & $8.8^{\mathrm{b}}$ & $8.9^{\mathrm{b}}$ & $7.5^{\mathrm{cd}}$ & $7.4^{\mathrm{d}}$ & $8.2^{c}$ \\
\hline
\end{tabular}

${ }^{* a-d}$ values with different letters in the same column are significant different at $P<.0 .05$.

CONCLUSION: Strawberry products like jam suffer from discoloration or color bleaching due to rapid degradation of pigments. Results from this study clearly showed that purple carrot puree have a high concentration of acylated anthocyanins made it more stable and suitable for mixing with strawberry during jam processing . Adding up to $20 \%$ of purple carrot puree during strawberry jam processing enhanced the color stabilization during and after six month of storage at room temperature without any effects on the other organoleptic attributes.

\section{REFERENCES}

1. A.O.A.C. 2005. Official Methods of the Analysis of AOAC. International18th Edition, Published by AOAC International. Maryland 20877- 2417. USA

2. Abonyi ,B.; H. Eng, J. T. Ang, C.G. Edwards, B.P. Chew, D.S. Mattinson and J.K. Felman. 2001. Quality retention in strawberry and carrot purees dried with Refractance Window ${ }^{\text {TM }}$ system. J. Food Sci. Vol. 67(2), 1051-1056 
3. Alasalvar C., J. M. Grigor, D. Zhang, P. C. Quantick . and F. Shahidi. 2001. Comparison of volatiles, phenolics, sugars, antioxidant vitamins and sensory quality of different colored carrot varieties. Journal of Agriculture and Food Chemistry, 49(3): 1410-1416.

4. Andersen, O.M. 1989. Anthocyanin in fruits of Vaccinium oxycoccus (small cranberry). J. Food Sci., 52:665-669.

5. Askar, A. 1993. Natural colors for the food industry - an overview. Fruit Processing, 3 (11), 400-403.

6. Askar, A. and H. Treptow. 1993. Quality assurance in tropical fruit processing. Spring Laboratory.

7. Attoe, E.L. and J. H. Van-Elbe. 1981. Photochemical degradation of betanin and selected Anthocyanins. J. Food Sci., 1934-1937.

8. Banga O. 1984. Carrot. pp: 291-293. In: Evolution of crop plants. (Simmonds N.W. 3th.ed.) Longman, London.

9. Birks, S. 1999. The potential of carrots. Food-Manufacture, 47(4), 22-23.

10. Downham, A., and P. Collins .2000. Colouring our foods in the last and next millennium. International J. of Food Science and Technology, 35(1), 5-22.

11. Espin JC, C. Soler-Rivas, H.J. Wichers and C. Garcia-Viguera. 2000. Anthocyaninbased natural colorants: a new source of antiradical activity for foodstuff. J. Agric. Food Chem. 48:1588-1592

12. Garcia, B.S.A., N.J. Nunes, and C.S. Silva .1998. Effect of different pre-freezing treatments on the quality of frozen strawberries variety Chandler $\mathrm{Ci}$. Technol. Aliment. 18, 82-86.

13. Howard L. R. and T. Dewi .1995. Sensory, microbiological and chemical quality of mini-peeled carrots as affected by edible coating treatment. Journal of Food Science 60 (1): 142-144.

14. Kammerer, D.R.; Sandra Schillm, O. Maier, A. Schieber and R. Carle. 2007. Colour stability of canned strawberries using black carrot and elderberry juice concentrates as natural colourants. Eur Food Res Technol. 224: 667-679.

15. Kırca, A., M. Ozkan and B. Cemeroglu. 2006. Stability of black carrot anthocyanins in various fruit juices and nectars. Food Chem. 97: 598-605.

16. Kong,J. M., L.S. Chia, N. K. Goh, T. F. Chia, and R. Brouillard. 2003. Analysis and biological activities of anthocyanins. Phytochem. 64, 923-933.

17. Mazza, G., and E. Miniati .1993. Anthocyanins in fruits, vegetables and grains . London: CRC Press.

18. Meydev, S., I. Sagy, and I.J. Kopelman. 1977. Browning determination in citrus products. J. Agric. Food Chem. 25(3): 502-604. 
19. Mondello L., A.Cotroneo, G. Errante, G. Dugo and P. Dugo. 2000. Determination of anthocyanins in blood orange juices by HPLC. J. Pharmaceutical and Biomedical Analysis, 23: 191-195.

20. Netzel M., G.Netzel, D. R. Kammerer, A. Schieber, R.Carle, L. Simons, I. Bitsch, R. Bitsch and I. Konczak. 2007. Cancer cell antiproliferation activity and metabolism of black carrot anthocyanins Innovative. Food Science and Emerging Technologies, 8: 365-372.

21. Prior, R. L., G. Cao, A. Martin, E. Sofic, J. McEwen and C. Brien. 1998. Antioxidant capacity as influenced by total phenolic and anthocyanin content, maturity and variety of Vaccinium species. Journal of Agriculture and Food Chemistry, 46: 2686-2693.

22. SPSS.1990. SPSS/PC for IBM PC/X1 Inc. Chicago, 1L. USA .

23. Stintzing, F. C., A. S. Stintzing, R. Carle, B. Frei, and R. E. Wrolstad .2002. Color and antioxidant properties of cyanidin-based anthocyanin pigments. Journal of Agricultural and Food Chemistry,50 (21), 6172-6181.

24. Suda, I., T. Oki, M. Masuda, M. Kobayashi, Y. Nishiba and S. Furuta. 2003. Physiological functionality of purple-fleshed sweet potatoes containing anthocyanins and their utilization in foods. Japan Agriculture Research Quarterly, 37: $167-173$.

25. Tulasidas, T.N., G.S.V. Raghavan, A.S. Mujumdar. 1993. Microwave and convective drying of grape. Trans ASAE 36: 1861 - 1865.

26. Vinson, J. A., Y. A. Dabbagh, M. S. Mamdouh and J. Jang. 1995. Plant flavonoids, especially tea flavonols are powerful antioxidants using an in vitro oxidation model for heart disease. J. Agric. and Food Chem. 43: 2800-2802.

27. Yoshida, K., T. Kondo and T. Goto. 1991. Unusually stable monoacylated anthocyanin from purple yam Discorea alata. Tetrahedron Letters, 32: $5579-5580$. 


\title{
ثبات لون مربى الفراولة المدعمة بيوريه الجزر البنفسجى
}

\author{
مجدى عبد الهادى ، جميلة يوسف عطية وعفاف محمد على \\ معطز بحوث تكنولوجيا الأغنية - مركز البحوث النزراعية - جيزة - مصر
}

يعتبر تدهور لون منتجات الفراولة كنتيجة لحدوث تكسير فى الصبغات احد اهم عيوب الجوده



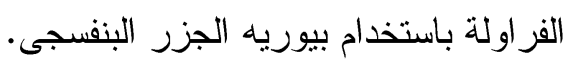
وقد اوضحت الننائج ان بيوريه الجزر كان متميزا فى ارتفاع محتواة من الفينولات الكلية و

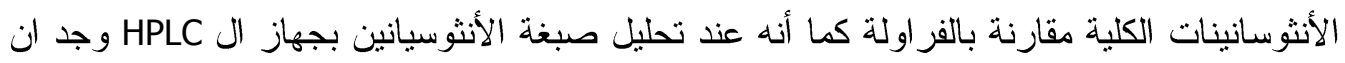

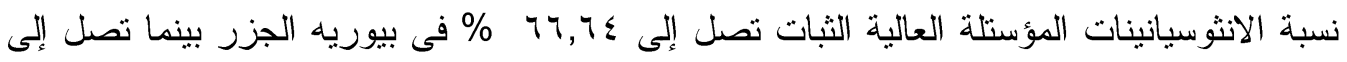

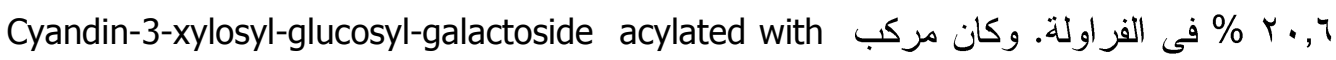
Ferulic acid



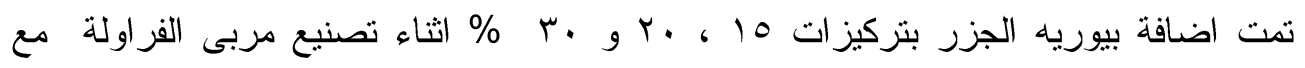



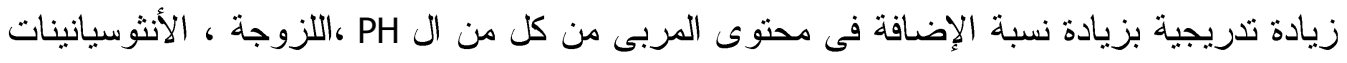

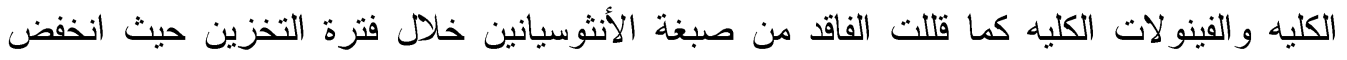

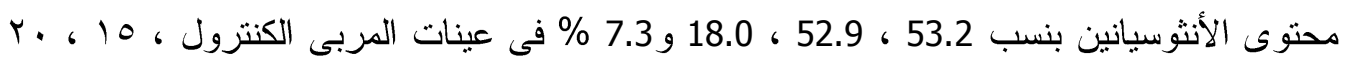

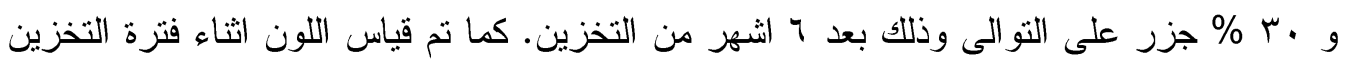

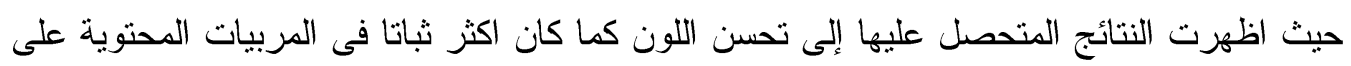

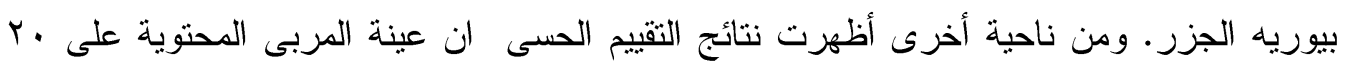
\% بيوريه جزر كانت الأكثر قبو لا عند نهاية فترة التخزين.

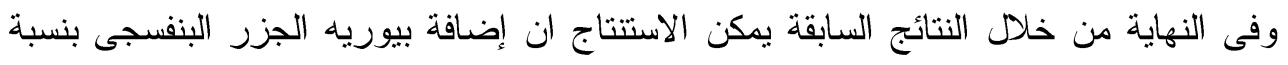

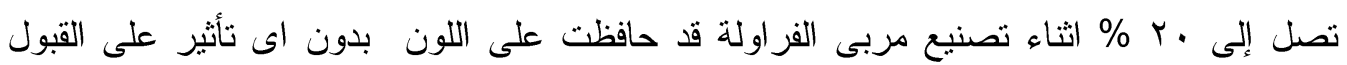

